\title{
DESAIN MODEL KONSTRUKSI DERMAGA / TERMINAL UKS BERBASIS PERKUATAN LERENG SUNGAI
}

\author{
Putera Agung Maha Agung1, Mursid ${ }^{2}$ \\ ${ }^{I}$ Geoteknik, Jurusan Teknik Sipil, Politeknik Negeri Jakarta \\ Jalan Prof.Dr.G.A.Siwabessy, Kampus UI - Depok, Kota Depok(16425) \\ E-mail: putera.agungmagung@sipil.pnj.ac.id \\ ${ }^{2}$ Geohidrolik, Jurusan Teknik Sipil, Politeknik Negeri Jakarta, Kota Depok (16425) \\ E-mail: mursid@sipil.pnj.ac.id
}

\begin{abstract}
ABSTRAK
Dermaga sungai atau Terminal Untuk Kebutuhan Sendiri (TUKS) adalah suatu bangunan dermaga yang digunakan untuk operasional khusus bongkar muat material bio-massa untuk Pusat Pembangkit Tenaga Listrik. Konstruksi TUKS yang direncanakan terletak di Daerah Aliran Sungai (DAS) Sungai Kapuas, Kalimantan Barat. Konstruksi dermaga TUKS ini tidak hanya berfungsi sebagai dermaga sungai, akan tetapi juga digunakan sebagai lahan beban imbang (counter weight) untuk menahan pergerakan lateral ke arah sungai. Secara umum, struktur TUKS menggunakan suatu konstruksi lapisan pelindung dari batu atau konstruksi revetment (rock armour revetment system). Desain TUKS menggunakan data geoteknik dan geohidrolik eksisting. Guna mempersingkat waktu untuk menaikkan kekuatan geser tanah di bawah konstruksi revetment, maka waktu konsolidasi dipercepat dengan menggunakan metode pra-pembebanan (preloading) dan PVD. Analisis kestabilan lereng menggunakan software PLAXIS untuk menentukan faktor keamanan (FK). Hasil-hasil desain menunjukkan konstruksi revetment mampu mengantisipasi pergerakan tanah ke arah sungai dan lebih ekonomis daripada metode - metode lainnya.
\end{abstract}

Kata Kunci: TUKS, revetment, pergerakan tanah, waktu konsolidasi, stabilitas lereng.

\begin{abstract}
River jetty or Own Needs Terminal (TUKS) is a building used for the special operation of loading and unloading bio-mass material for a Power Plant. TUKS designed is located in the Kapuas River Basin, West Kalimantan. Construction of TUKS is not only as a function of river jetty, but also used as an area for counterweight to retain lateral movement towards the river. In general, the TUKS structure uses a revetment construction (or a rock armour revetment system). TUKS design uses existing geotechnical and geohydraulic data. In order to shorten the time for increasing the shear strength of soil below the revetment construction, the time rate of consolidation is accelerated by using preloading and PVD methods. Slope stability analysis uses PLAXIS software in determining the safety factor (SF). The design results show that the revetment construction is able to anticipate soil movement towards the river and more economic than the other methods.
\end{abstract}

Keywords: TUKS, revetment, lateral movement, time rate of consolidation, slope stability.

\section{PENDAHULUAN}

Berdasarkan hasil-hasil studi pendahuluan, perencanaan dermaga/Terminal Untuk Kebutuhan Sendiri (TUKS) Power Plant Wajok Hulu, Siantan, Pontianak, Kalimantan Barat, dapat diketahui bahwa area perencanaan dermaga memiliki luas kurang lebih $1500 \mathrm{~m}^{2}$ berada di tepi Aliran Sungai Kapuas dan data tipikal uji lapangan tipikal CPT (Gambar 1). Perencanaan struktur dermaga terdahulu menggunakan sistem sheet pile wall yang dikombinasikan dengan sistem perkuatan spun pile (Gambar 2).

Perencanaan dermaga TUKS ini, memiliki beberapa fungsi utama, yaitu: (1) struktur dermaga harus mampu menahan pergerakan lateral dari beban dinamis dari bagian-bagian struktur penting Power Plant, antara: chiller; boiller; dan turbine, dsb.; (2) mampu menahan pergerakan lateral bagian atas tiang pancang (spun pile), sehingga tidak terjadi perputaran (tilting) pada spun pile; (3) mampu menahan kelongsoran atau bidang gelincir yang melalui lapisan tanah lunak (soft soil); (4) mampu mengarahkan aliran rembesan (seepage) dari Sungai Kapuas, sehingga kadar air ( $\mathrm{w}_{\mathrm{opt}}$ ) dan berat volume kering maksimum tetap stabil $\left(\gamma_{\text {dmaks }}\right)$ pada lahan yang akan direncanakan untuk dermaga, sebagaimana diperlihatkan dalam Gambar 3. Konstruksi yang dipilih juga harus ekonomis, bila dibandingkan dengan jenis konstruksi-konstruksi lainnya. 

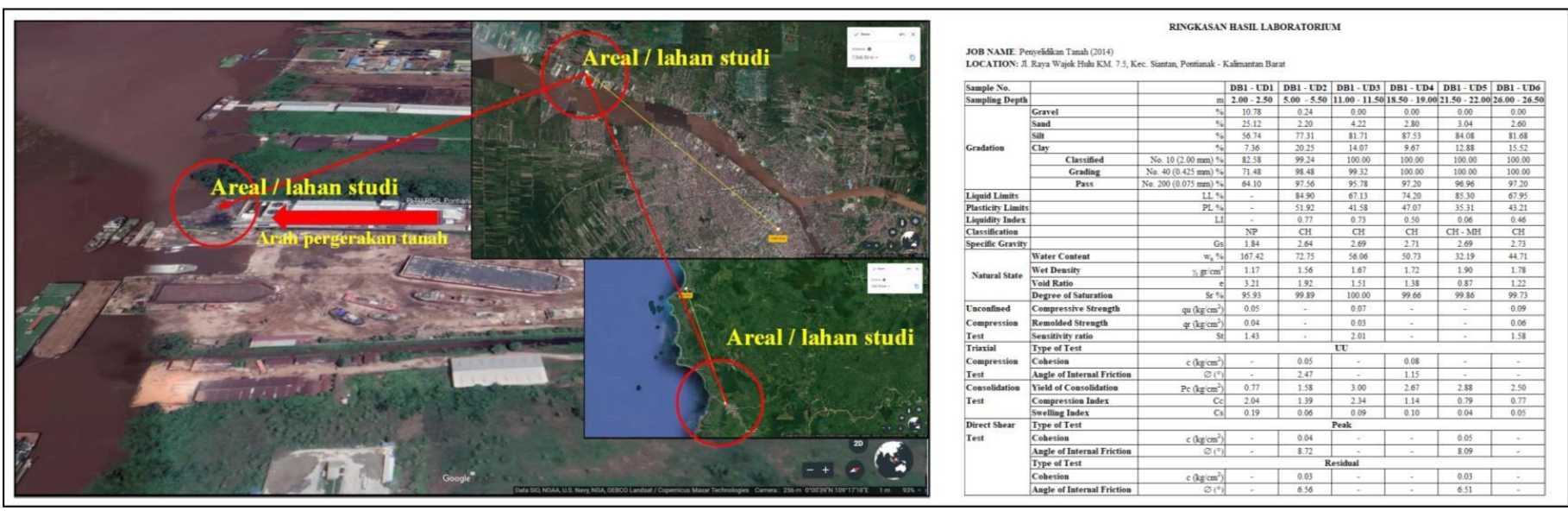

Gambar 1: Areal / lahan studi dan data lapangan tipikal CPT (cone penetration test) dan arah pergerakan tanah (Sumber: Laporan penyelidikan tanah / geoteknik PT. Tarumanegara Bumiyasa, 2014)

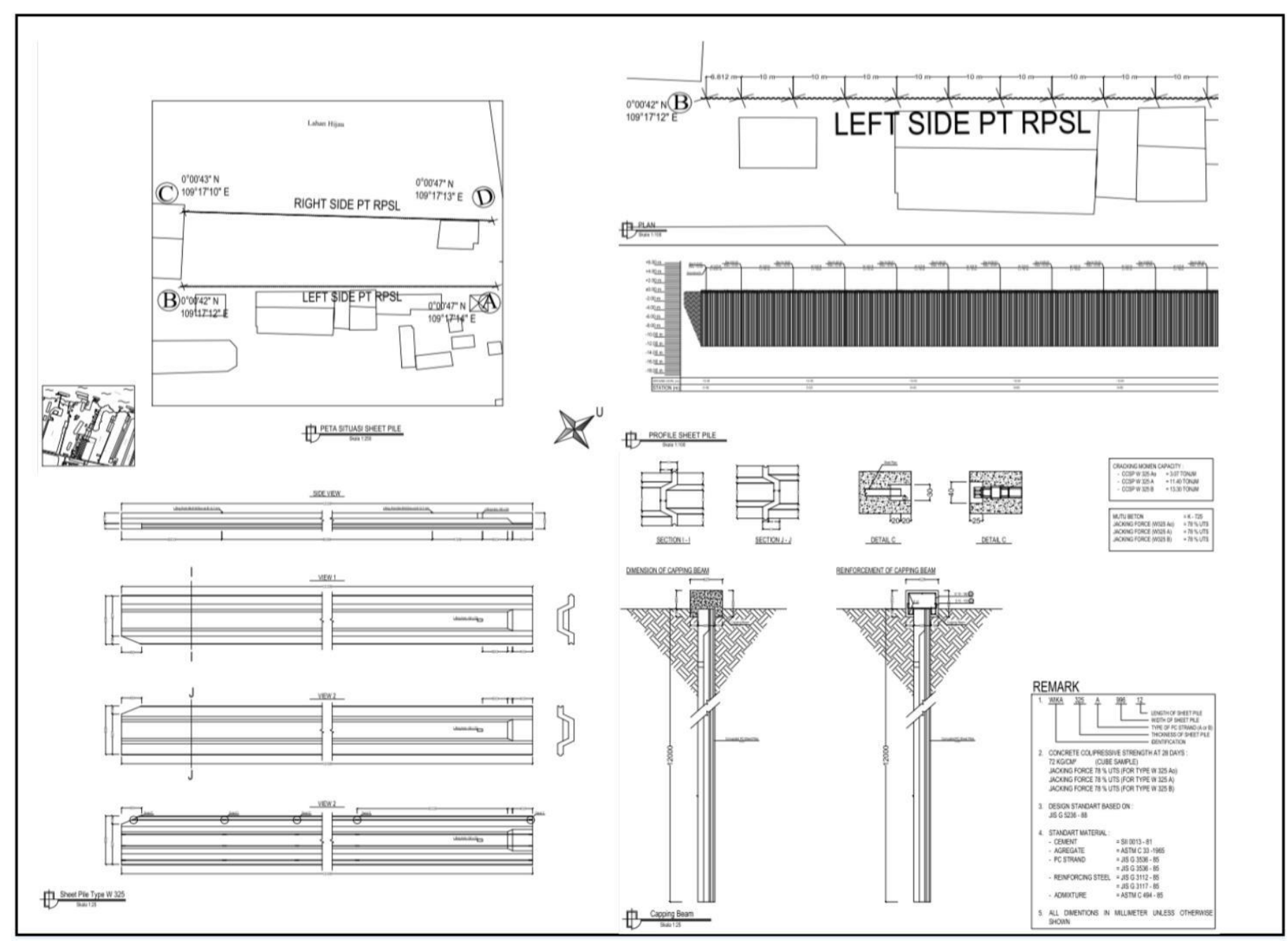

Gambar 2: Desain awal tipikal menggunakan sistem sheet pile wall yang dikombinasikan dengan sistem perkuatan spun pile 


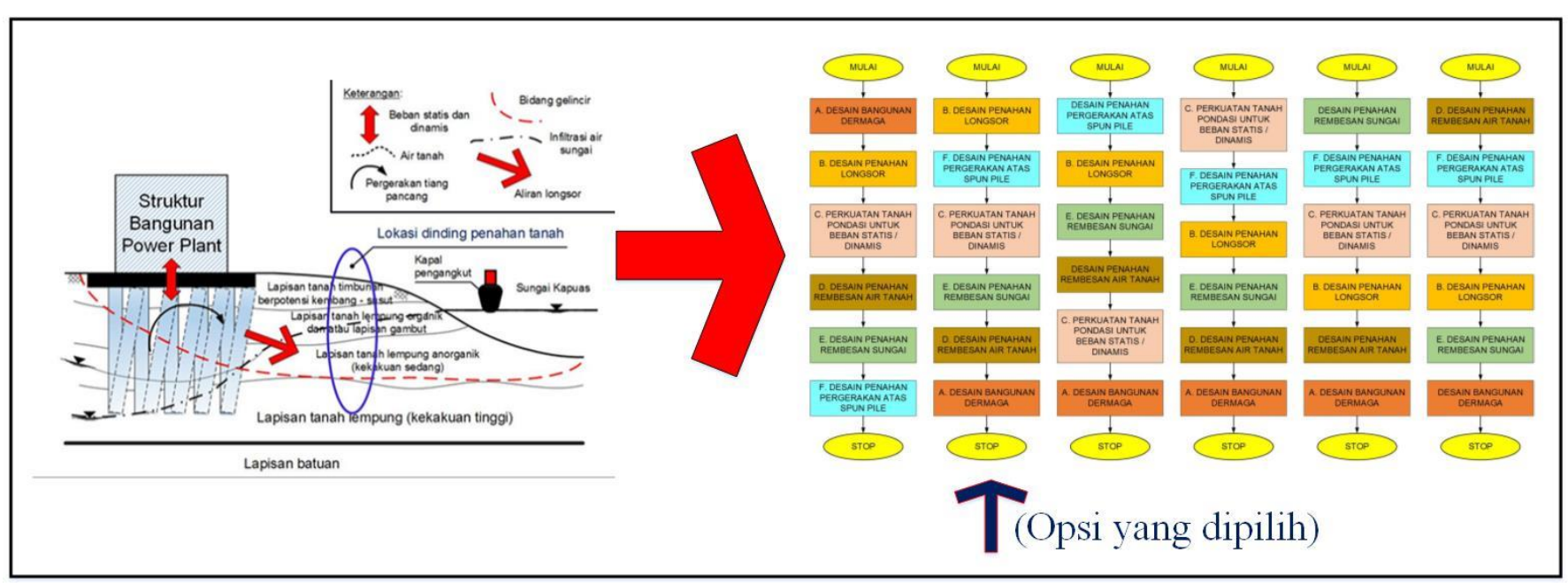

Gambar 3: Fungsi utama dermaga dan analisis detail rancangan untuk pemilihan tipe dermaga dan opsi yang dipilih

Dari Gambar 3, dapat diketahui bahwa ruang lingkup untuk pekerjaan dermaga, terdiri atas 6 (enam) pekerjaan. Sehingga harus dipilih berdasarkan: (1) Metode konstruksi; (2) Konstruksi tambahan (temporary sheet pile, dsb.); (3) Gangguan pelaksanaan (lalu lintas angkutan Power Plant, dsb.); (4) Ketersediaan material (batu kali/bongkahan, pasir, dsb.); (5) Ketersediaan peralatan (alat berat untuk pancang, bor, dsb.); (6) Tenaga kerja (lokal, level/tingkat kemampuan, dsb); (7) Waktu (efisiensi pengelolaan, pengangkutan material, jalan akses, dsb.); (8) Biaya (sesuai dengan kemampuan perusahaan Power Plant, dsb.); (9) Risiko konstruksi (pergerakan yang tidak diperhitungkan, dsb.). Dari hasil analisis kelayakan, maka skor yang dipilih adalah yang memiliki nilai $\leq 16$. Hal ini menunjukkan bahwa di dalam desain dermaga tidak semata-mata untuk kebutuhan dermaga saja, melainkan sistem dermaga juga memiliki fungsi lain, yaitu: (1) Mampu menahan pergerakan longsor ke arah Sungai Kapuas; (2) Mampu menahan pergerakan bagian atas spun pile struktur Power Plant eksisting, akibat beban statis dan dinamis, walaupun bagian dasar tetap memegang lapisan tanah fondasi; (3) Mampu meredam semua pembebanan statis dan dinamis; (4) Mampu mengarahkan pergerakan rembesan air Sungai Kapuas dan air tanah saat musim hujan; (5) Mampu dilaksanakan dengan ekonomis dan tepat guna. Dengan mempertimbangkan semua hal di atas, maka sangat diperlukan proses konsolidasi pendahuluan di lahan dermaga, sehingga kuat geser tanah menjadi meningkat dan tanah mampu memikul semua beban statis dan dinamis atau berfungsi sebagai beban imbang (counter weight) untuk menahan semua pergerakan (displacement) baik vertikal maupun horizontal. Hal ini untuk menghindari pemancangan spun pile hingga lapisan keras dan sudah pasti sangat mahal (costly). Paper ini bertujuan hanya untuk membahas penggunaan tipe penahan longsor berupa dinding penahan tanah (revetment) di lahan counter weight untuk diterapkan dalam sistem dermaga TUKS. Pertimbangan ini didasarkan atas alasan ekonomis dari pemilik proyek dan kemudahan pelaksanaan di lapangan.

\section{METODOLOGI}

\subsection{Bagan alir secara umum}

Secara garis besar, kegiatan-kegiatan di atas dapat dikelompokkan dalam 3 (tiga) fase. Fase Pertama terdiri atas: (a) tahap persiapan; (b) tahap pengumpulan data sekunder; (c) tahap survei pendahuluan; (d) tahap pemilihan opsi pendahuluan. Dalam Fase Kedua adalah tahap pengumpulan data primer / survei teknis. Fase Ketiga adalah meliputi tahap analisis data survei dan perencanaan teknis penanganan pergerakan lateral dari lahan Power Plant dan tahap penyusunan dokumen teknis. Secara umum dapat diperlihatkan dalam Gambar 4.

\subsection{Penyusunan parameter tanah}

Penyelidikan Tanah di area perencanaan dermaga di daerah Wajok Hulu, Siantan, Pontianak, Kalimantan Barat, dapat disimpulkan sebagai berikut (sumber data: Laporan Hasil Penyelidikan Geoteknik Laboratorium Mekanika Tanah, Fakultas Teknik Universitas Tanjungpura, 2018), yaitu: (1) Titik Bor 1 (DB.1), lapisan tanah sangat lunak hingga lunak (very soft to soft) kedalaman 0,00 hingga 17,00 m; (2) Lapisan tanah lempung organik setengah kaku hingga kaku (medium stiff to stiff), kedalaman 18,00 hingga 28,00 m; (3) Lapisan tanah sangat kaku hingga keras (very stiff to hard), kedalaman 30,00 hingga $40,00 \mathrm{~m}$.

Kekuatan geser tanah pada lapisan tanah lunak (soft soil) hingga kedalaman antara 5,0 hingga 15,0 m sebagaimana Laporan Pendahuluan adalah: (1) Nilai kohesi (c) adalah berkisar antara 0,1 hingga $0,12 \mathrm{~kg} / \mathrm{cm}^{2}$, atau sekitar $1,0 \mathrm{hingga} 1,2 \mathrm{t} / \mathrm{m}^{2} ;(2)$ Nilai sudut geser dalam $(\phi)$ adalah berkisar antara 5 hingga $10^{\circ}$; (3) Kuat tekan bebas $\left(\mathrm{q}_{\mathrm{u}}\right)$ adalah berkisar 0,1 hingga 0,15 
$\mathrm{kg} / \mathrm{cm}^{2}$ atau hanya sekitar 1,0 hingga $1,5 \mathrm{t} / \mathrm{m}^{2}$; (4) Daya dukung (bearing capacity) adalah $1,2 \mathrm{t} / \mathrm{m}^{2}$ hingga 4,4 t/m $2(\mathrm{SPT})$, sedangkan daya dukung untuk tiang tunggal spun pile dia. $30 \mathrm{~cm}$ adalah 6,5 hingga $10,3 \mathrm{t} / \mathrm{m}^{2}$.

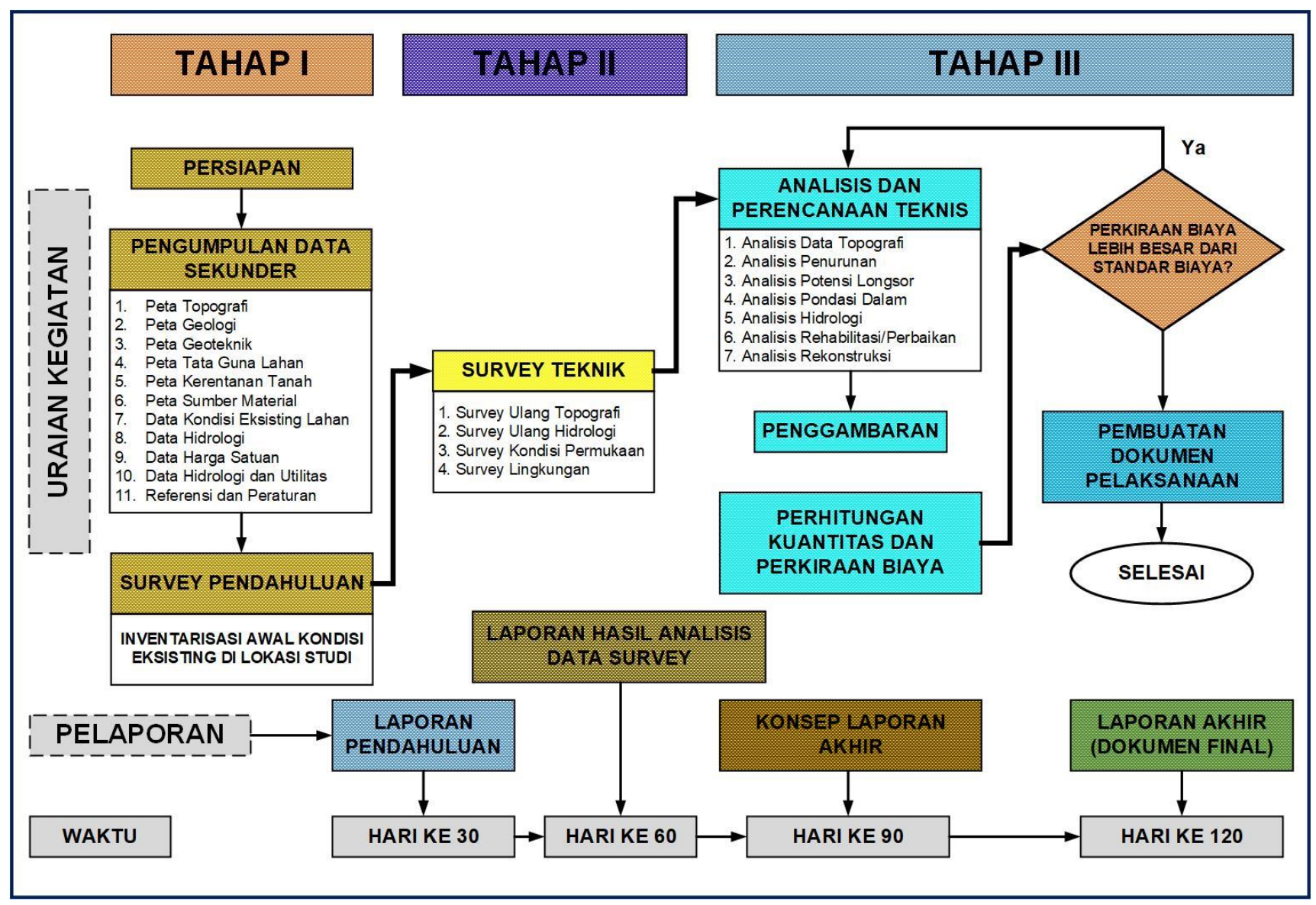

Gambar 4. Bagan alir metodologi secara umum

Data tahun 2014 (Gambar 1) dan 2018 ini dikonfirmasi dengan data hasil uji lapangan terakhir pada tahun 2020 (sumber: Laporan Penyelidikan Tanah / Geoteknik, Jurusan Teknik Sipil, Politeknik Negeri Bandung), sebagaimana diperlihatkan dalam Gambar 4. Ternyata hasil yang dicapai telah terjadi peningkatan kekuatan geser selama 6 (enam) tahun pada areal tersebut.

\subsection{Model pembebanan operasional bongkar muat}

Untuk parameter input pembebanan pada PLAXIS diambil berdasarkan standar pembebanan SNI 1725-2016. Secara ringkas beban-beban yang harus diperhitungkan dalam perencanaan TUKS dapat dilihat pada Tabel 1. Kombinasi beban didasarkan kepada beberapa kemungkinan tipe yang berbeda dari aksi yang bekerja secara bersamaan. Tabel 1 juga memperlihatkan kombinasi beban pada masa pelaksanaan (1) dan masa pelayanan (2). Dalam masa pelaksanaan hanya diperhitungkan beban alat berat, yaitu $128 \mathrm{kN} / \mathrm{m}^{2}$, sedangkan untuk masa pelayanan / operasional diperhitungkan untuk aksi tetap (beban perkerasan; beban "D"; beban "T" dan beban rem) sebesar $83,9 \mathrm{kN} / \mathrm{m}^{2}$.

\subsection{Analisis metode pelaksanaan}

Pra-pembebanan (preloading) menambah daya dukung dan mengurangi kompresibilitas dari tanah lunak. Preloading membuat tanah pasiran lepas menjadi padat, ataupun membuat tanah lempung dan lanau terkonsolidasi (Hausmann, 1990). Solusi sederhana untuk preloading adalah pembebanan langsung dengan menggunakan timbunan. Meskipun dapat dilakukan pada semua jenis tanah, preloading lebih efektif diterapkan pada tanah kohesif lunak. Ketika beban ditempatkan di atas tanah lunak, itu merupakan awal dari mengatasi tekanan air pori (pore water pressure). Ketika tanah tidak terlalu lolos air (permeable), tekanan air pori akan berkurang secara bertahap, karena air pori hanya mampu mengalir sangat lambat ke arah vertikal (Holtz \& Kovacs, 1981). Agar tidak menimbulkan masalah stabilitas, timbunan harus ditempatkan dalam dua lapis atau lebih. 


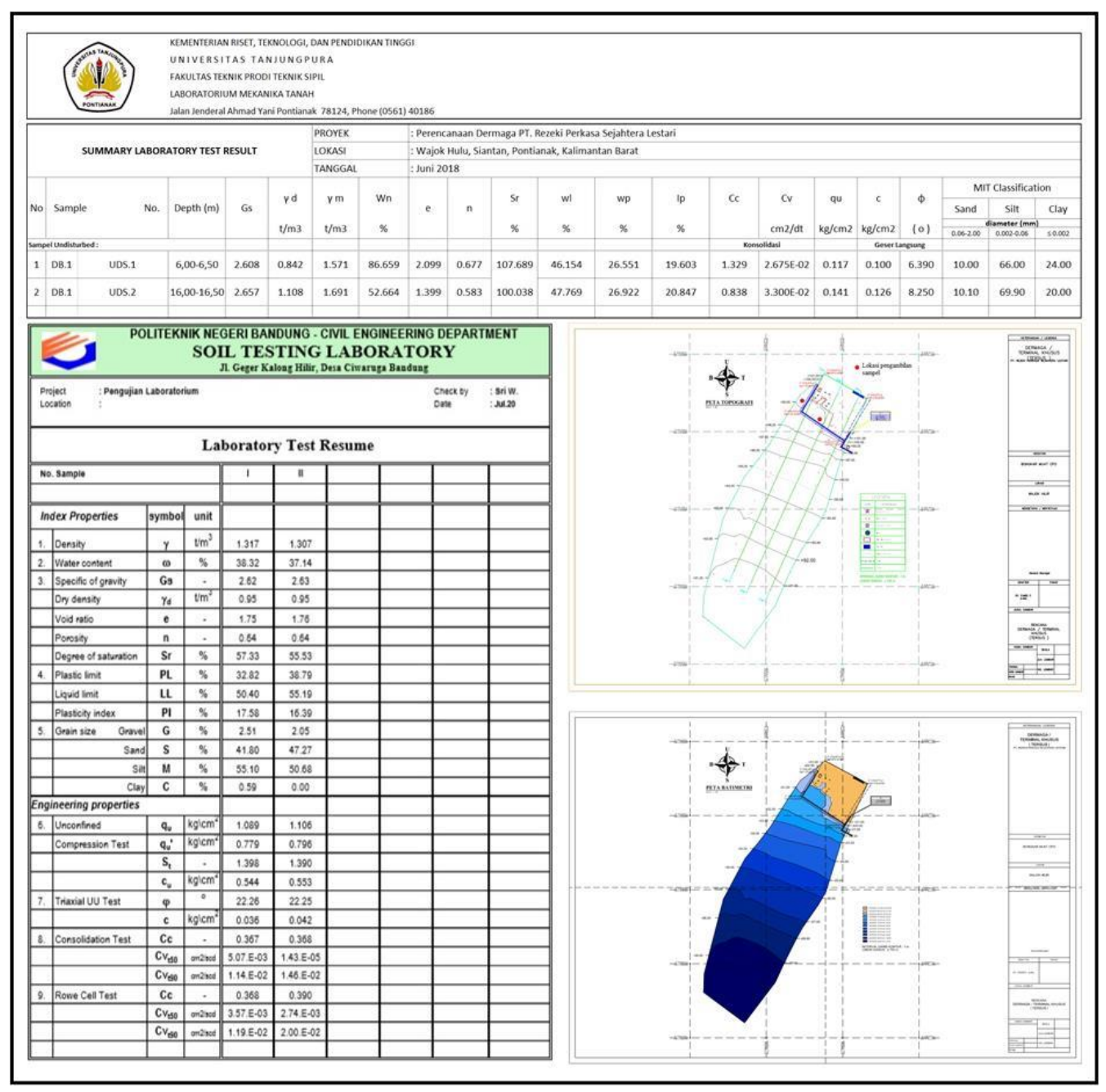

Gambar 5. Hasil penyelidikan tanah tahun 2020 dan peta Topografi / Batimetri

Tabel 1. Jenis dan kombinasi beban pada perencanaan dermaga TUKS (SNI 1725 2016)

\begin{tabular}{|c|c|c|c|}
\hline \multicolumn{4}{|c|}{ SNI 1725 - 2016} \\
\hline $\begin{array}{c}\text { Jenis beban } \\
\text { (simbol) }\end{array}$ & Aksi & $\begin{array}{c}\text { Jenis beban } \\
\text { (simbol) }\end{array}$ & Aksi \\
\hline \multirow{2}{*}{\begin{tabular}{|l} 
Beban mati \\
komponen \\
struktural dan non \\
struktural (MS)
\end{tabular}} & Tetap & $\begin{array}{l}\text { Gaya Sentrifugal } \\
\text { (TR) }\end{array}$ & Transien \\
\hline & \multirow[b]{2}{*}{ Tetap } & $\begin{array}{l}\text { Beba } \\
\text { Kaki }\end{array}$ & Transier \\
\hline $\begin{array}{l}\text { perkerasan dan } \\
\text { utilitas (MA) }\end{array}$ & & $\begin{array}{l}\text { Gaya tumbukan } \\
\text { kapal (TV) }\end{array}$ & Transien \\
\hline $\begin{array}{l}\text { Gaya akibat susut } \\
\text { / rangkak }(\mathrm{SH})\end{array}$ & Transien & $\begin{array}{l}\text { Beb } \\
\text { pent }\end{array}$ & Transien \\
\hline \multirow{3}{*}{\begin{tabular}{|l|} 
Prategang (PR) \\
Gaya horizontal \\
akibat tekanan \\
tanah (TA)
\end{tabular}} & Tetap & \multirow{2}{*}{$\begin{array}{l}\text { Gaya akibat } \\
\text { temperatur gradien } \\
\text { (ET)/seragam } \\
\text { (Eun) }\end{array}$} & \multirow{2}{*}{ Transien } \\
\hline & \multirow[t]{2}{*}{ Tetap } & & \\
\hline & & Beban arus dan & \multirow[b]{2}{*}{ Transier } \\
\hline Gaya-gaya yang & \multirow{3}{*}{ Tetap } & has & \\
\hline $\begin{array}{l}\text { struktur dermaga } \\
\text { akibat proses }\end{array}$ & & Gaya apung (EF) & Transien \\
\hline & & \multirow{3}{*}{$\begin{array}{l}\text { Beban angin pada } \\
\text { struktur (Ews) }\end{array}$} & \multirow{3}{*}{ Transier } \\
\hline $\begin{array}{l}\text { Beban lajur "D" } \\
\text { (TD) }\end{array}$ & Transien & & \\
\hline $\begin{array}{l}\text { Beban Truk "T" } \\
\text { (TT) }\end{array}$ & Transien & & \\
\hline $\begin{array}{l}\text { Gaya akibat rem } \\
\text { (TB) }\end{array}$ & Transien & Gaya friksi (BF) & Transien \\
\hline
\end{tabular}
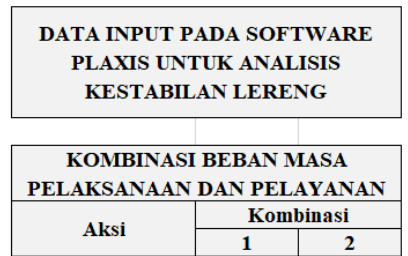

\begin{tabular}{|l|c|c|}
\hline Aksi tetap & $\mathrm{X}$ & $\mathrm{X}$ \\
\hline Beban lalu lintas & $\mathrm{X}$ & $\mathrm{O}$ \\
\hline Pengaruh temperatur & $\mathrm{O}$ & $\mathrm{O}$ \\
\hline $\begin{array}{l}\text { Arus/hanyutan/hidro } \\
\text { /daya apung }\end{array}$ & $\mathrm{O}$ & $\mathrm{O}$ \\
\hline Beban angin & $\mathrm{O}$ & $\mathrm{O}$ \\
\hline Pengaruh gempa & $\mathrm{O}$ & $\mathrm{O}$ \\
\hline Beban tumbukan & $\mathrm{O}$ & $\mathrm{O}$ \\
\hline Beban pelaksanaan & $\mathrm{X}$ & $\mathrm{X}$ \\
\hline $\mathrm{X}=$ Beban yang digunakan \\
\hline O = Beban yang tidak digunakan \\
\hline
\end{tabular}


Beban sementara tambahan dapat dipindahkan ketika penurunan melebihi prediksi penurunan akhir. Hal ini sebaiknya tidak terjadi sebelum kelebihan tekanan awal tersisa di bawah tekanan yang disebabkan oleh beban tambahan sementara. Dengan menambah waktu kelebihan sementara, atau ukuran beban tambahan, penurunan sekunder dapat berkurang atau bahkan dihilangkan. Ini dikarenakan menggunakan beban tambahan yang lebih tinggi dibandingkan dengan beban yang bekerja, tanah akan selalu dalam kondisi terkonsolidasi berlebih (overconsolidated) dan pemampatan sekunder untuk tanah overconsolidated sangat kecil dibanding dengan penurunan konsolidasi tanah normal.

Sebagaimana Pasal 6.9.5 dalam SNI 8460: 2017, analisis stabilitas tanah asli dengan menggunakan PVD dengan prapembebanan (preloading), maka beban total timbunan tanah yang diaplikasikan ke tanah asli diambil 1,30 kali beban yang direncanakan pada kondisi layan bila efek gaya angkat (bouyancy effect) yang diterima beban timbunan pada saat proses preloading berlangsung tidak diperhitungkan. Sedangkan jika efek gaya angkat (bouyancy effect) yang diterima beban timbunan pada saat proses preloading diperhitungkan, maka beban total preloading berupa timbunan tanah yang diaplikasikan ke tanah asli harus lebih besar atau sama dengan 1,20 kali beban yang direncanakan pada kondisi layan.

Oleh karena lokasi TUKS terletak dataran rendah atau di daerah aliran Sungai Kapuas dan berfungsi sebagai area beban imbang (counter weight) bangunan power plant, maka areal tanah lunak di sekitar dermaga harus dimampatkan dengan cepat dan kekuatan geser segera meningkat. Metode percepatan konsolidasi dengan menggunakan pemasangan PVD (prefabricated vertical drain) menjadi alternatif desain untuk mempercepat pembuangan tekanan air pori berlebih yang dikombinasikan dengan metode pra-pembebanan (preloading). Perencanaan PVD (prefabricated vertical drain) dilaksanakan berdasarkan teori Barron (1948) dan Hansbo (1997), antara lain: pengurangan panjang jalur air pori dan analisis pemilihan formasi segitiga atau segi empat untuk mempercepat terjadinya penurunan (settlement). Pemasangan PVD dirancang dengan menggunakan rasio smear zone atau $\mathrm{d}_{\mathrm{s}} / \mathrm{d}_{\mathrm{w}} \geq 3,0$ sesuai dengan kondisi tanah lunak eksisting di daerah studi dan untuk rasio permeabilitas atau $\mathrm{k}_{\mathrm{h}} /$ $\mathrm{k}_{\mathrm{s}}$ diambil $=2,0$.

Pemodelan geometri PLAXIS untuk pelaksanaan stabilisasi tanah di areal dermaga / terminal TUKS adalah dengan menggunakan model regangan bidang (plane-strain) 15-Elemen Nodal, sebagaimana diperlihatkan dalam Gambar 6. Beberapa model analisis stabilitas lereng yang serupa telah dilakukan oleh El-Ramly et al., 2003; Jiang et al. 2014; Zhou et al., 2003; Suchomel \& Masŝin, 2010; Zhang et al., 2010 untuk memperkirakan besarnya faktor keamanan (safety factor), oleh karena sulitnya menentukan kekuatan geser tanah asli dan distribusi tekanan air pori yang akan timbul.

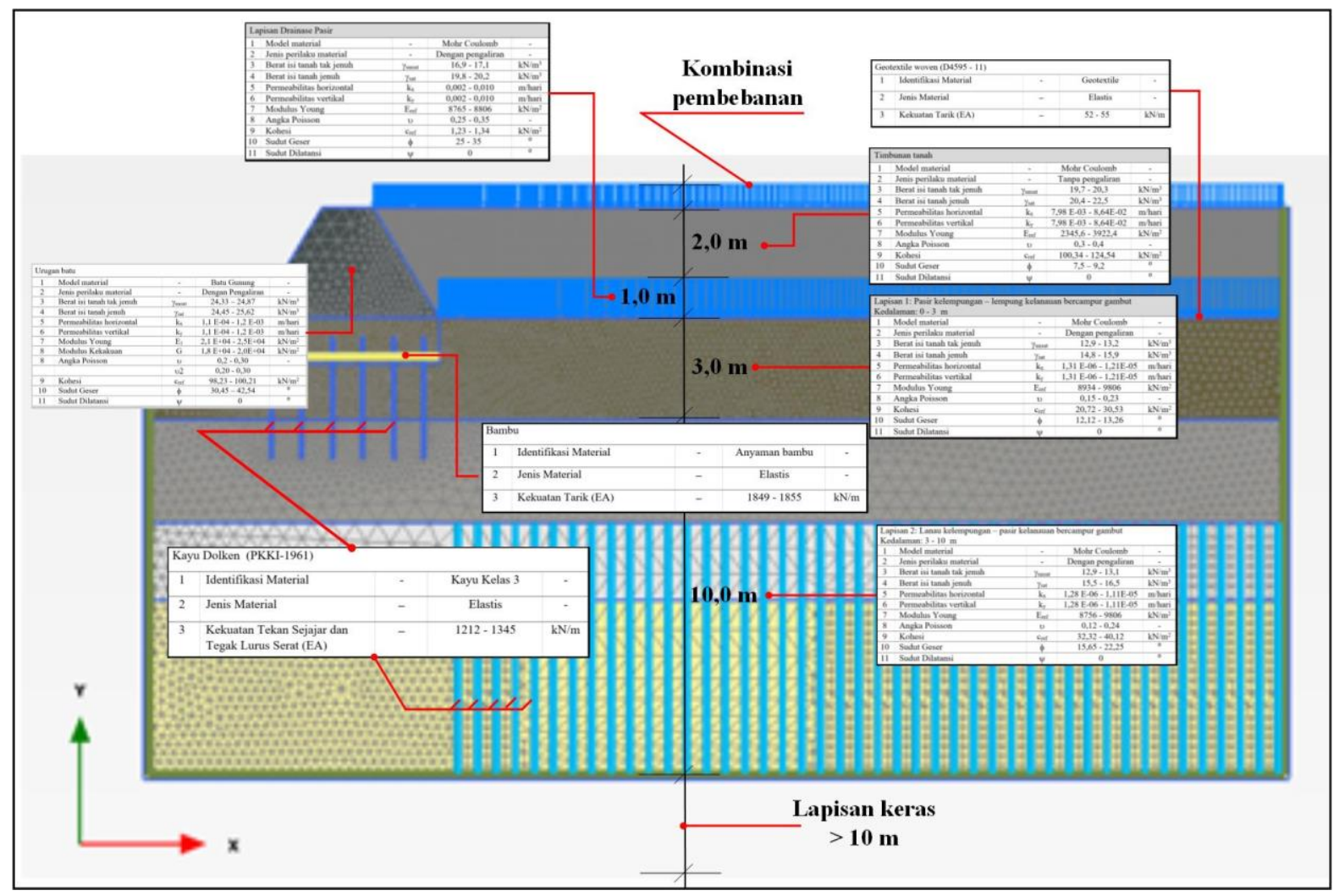

Gambar 6. Model geometri penampang untuk dermaga TUKS 


\subsection{Kondisi aliran permukaan dan bawah (rembesan air sungai)}

Data curah hujan tahun 1982 sampai dengan tahun 2015 digunakan untuk memprediksi perubahan curah hujan yang terjadi di DAS Kapuas. Oleh karena, data debit air Sungai Kapuas pada tahun 1982 hingga tahun 2015 tidak tersedia, maka data curah hujan yang tersedia di stasiun BMKG Bandar Udara Supadio, Pontianak digunakan untuk menentukan muka air rata-rata (mean water level) atau (dianggap \pm Elv. 0,00), muka air tinggi (high water level, dan muka air rendah (low water level), sebagaimana diperlihatkan dalam Gambar 7. Data dari berbagai studi dan BMKG, Pontianak (2019) diplot ulang sebagai data referensi untuk mempertimbangkan fluktuasi ketinggian muka air di daerah studi. Pada tahun 2018, muka air Sungai Kapuas mencapai ketinggian muka air 2,50 m dan bertahan hingga 3 hari pada tanggal 17 hingga 20 Januari 2018 (sumber: Republika.co.id, 2018). Hal ini disebabkan oleh perubahan cuaca ekstrem yang terjadi dan perubahan tata guna lahan, selain itu juga kawasan Mempawah secara topografi berada di antara minus 60 sampai plus 80 sentimeter dari muka air pasang tertinggi. Jika air pasang, kawasan Mempawah yang paling tinggi dari muka air sungai adalah sekitar 80 sentimeter.

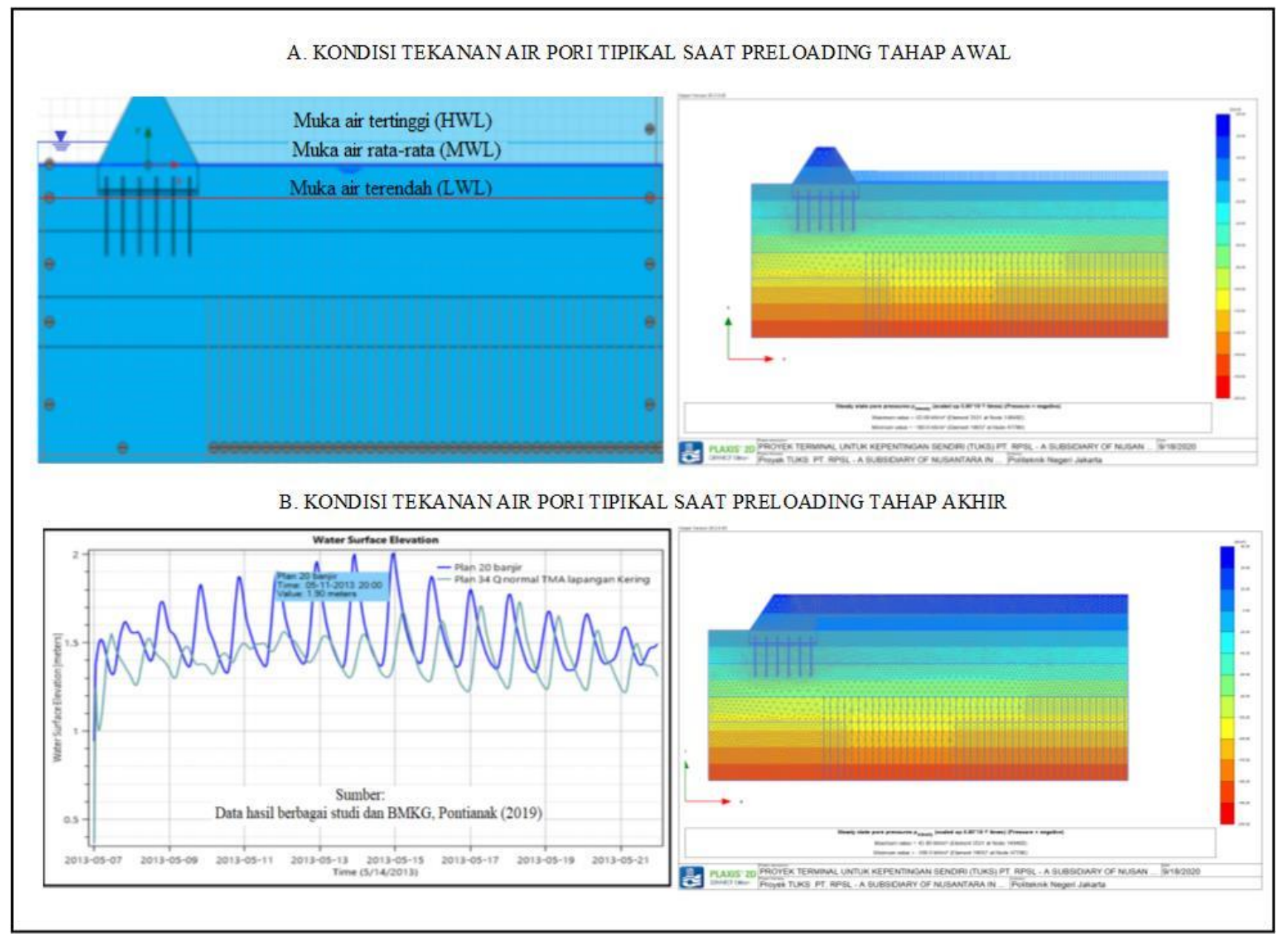

Gambar 7. Kondisi tekanan pori tipikal saat pembebanan (preloading) awal dan akhir

\section{ANALISIS DAN PEMBAHASAN}

\subsection{Model lapisan tanah}

Parameter - parameter lapisan tanah ditentukan dengan menggunakan data laboratorium dan data lapangan (SPT dan CPT/sondir). Lapisan - lapisan tanah eksisting dibandingkan dengan hasil plot data sondir (Robertson \& Campanella, 1983; Kulhawy \& Mayne, 1990; dan Robertson, 2009). Parameter berat volume tanah $(\gamma)$ di areal studi yang tidak diketahui ditentukan dengan menggunakan korelasi parameter dari Taylor (1948); Holtz \& Kovacs (1981); Carter \& Bentley, (1991); Veruijt (2006); dan Das (2011). Nilai-nilai kekuatan geser (c') dan ( $\phi$ ') ditentukan berdasarkan data eksisting dan dibandingkan dengan korelasi dari Schmertmann (1978); NAVFAC (1986); Look (2007); Griffiths et al. (2009); dan Di Matteo et al. (2013). Nilai Modulus Young (E) didekati dengan korelasi dari Lambe \& Whitman (1969); dan Jamiolkowski et al. (1979). Poisson ratio (u) ditentukan berdasarkan Bowles (1986); Kulhawy \& Mayne (1990); dan Lambe \& Whitman (1979). Sudut dilatasi $(\psi)$ dinyatakan dalam derajat oleh Bolton (1986), umumnya tanah lunak cenderung memiliki dilatansi kecil dan dianggap sama dengan nol (0). 


\subsection{Tahapan pelaksanaan pekerjaan dermaga / terminal TUKS}

Tahapan - tahapan analisis diawali dengan tahap pra-pembebanan (preloading), yaitu tahap 1 \& 2 dikombinasikan dengan pemasangan PVD; kemudian dilanjutkan dengan pelaksanaan konstruksi jalan akses; dan tahap pasca konstruksi (tahap operasional) selama 10 tahun. Tahap konstruksi merupakan tahap timbunan selama konstruksi timbunan sampai tahap perkerasan. Waktu pelaksanaan konstruksi dermaga / terminal TUKS ditentukan selama 116 hari atau lebih kurang 4 bulan. Sementara tahap pasca konstruksi (tahap operasi) selama 10 tahun merupakan tahap konsolidasi tanah yang terjadi selama 10 tahun akibat beban lalu lintas. Untuk tahapan-tahapan analisis menggunakan software PLAXIS dapat dilihat pada Tabel 2.

\subsection{Hasil analisis penurunan dengan metode preloading dan PVD (prefabricated vertical drain)}

Berdasarkan tabel di atas, didapatkan waktu konsolidasi metode preloading lebih lama dibandingkan dengan metode PVD konsolidasi (PVD consolidation method). Untuk mencapai derajat konsolidasi yang sama (> 90\%), metode preloading PVD hanya memerlukan waktu 183 hari saja untuk menyelesaikan pemampatan tanah dengan penurunan maksimum 2,421 m saat pelaksanaan, sedangkan untuk metode preloading saja adalah lebih dari (>) 393 hari (Gambar 8).
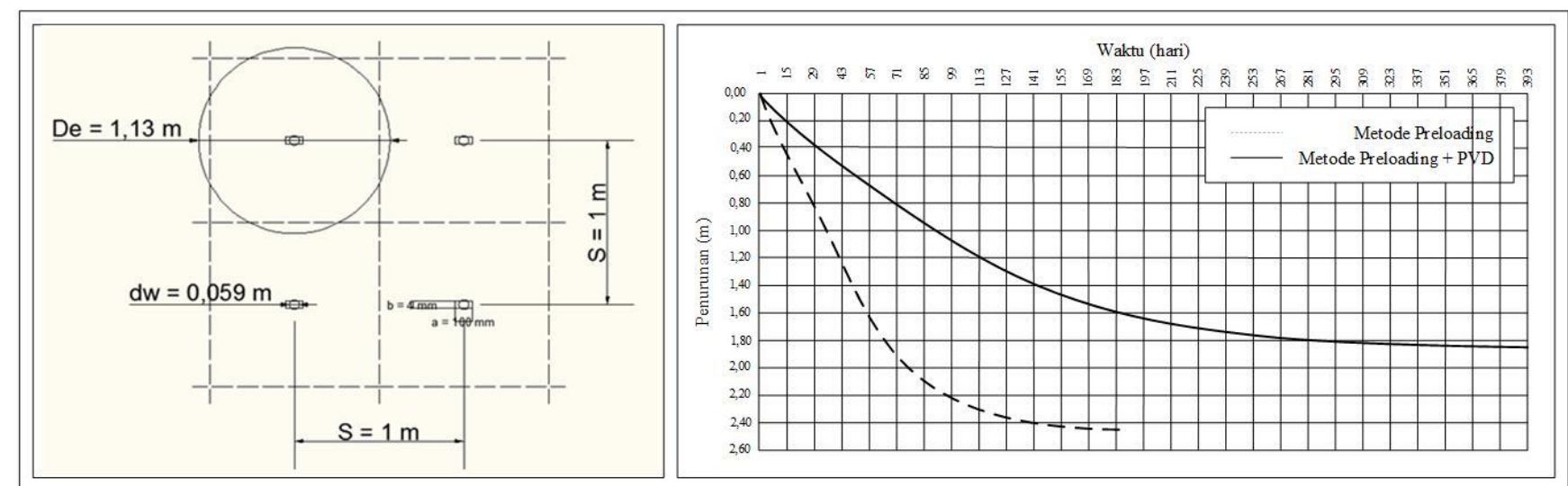

Gambar 8. Detail pemasangan dan grafik hubungan antara penurunan tanah versus waktu saat pelaksanaan (tipikal)

\subsection{Hasil analisis stabilitas dan pergerakan tanah pada program PLAXIS}

Hasil-hasil analisis stabilitas untuk menentukan besarnya penurunan (settlement) dan faktor keamanan atau FK (safety factor) pada tahap pelaksanaan preloading yang dikombinasikan dengan pemasangan PVD diperlihatkan Gambar 9. Kondisi besarnya penurunan dan angka keamanan saat konstruksi jalan akses diperlihatkan dalam Gambar 10. Dan, Gambar 9 juga menunjukkan besarnya penurunan yang terjadi setelah 10 tahun dan besarnya angka keamanan yang tercapai.

Tabel 2. Tahapan pelaksanaan pekerjaan konstruksi dermaga / terminal TUKS

\begin{tabular}{|c|c|c|c|c|c|}
\hline No. & Fase & Hari & $\begin{array}{l}\text { Total hari } \\
\end{array}$ & Tipe Perhitungan & \\
\hline 1. & Kondisi awal & 0 & 0 & - & \\
\hline 2. & Pemasangan PVD & 7 & 7 & Consolidation analysis & \\
\hline 3. & Timbunan awal tahap 1 & 24 & 31 & Consolidation analysis & \\
\hline 4. & Timbunan awal tahap 2 & 24 & 55 & Consolidation analysis & \\
\hline 5. & Konsolidasi $90 \%$ & 3589 & - & Consolidation analysis & \\
\hline 6. & Konstruksi eksisting jalan & 30 & 85 & Consolidation analysis & \\
\hline 7. & Operasional eksisting jalan & 3650 & 3735 & Consolidation analysis & \\
\hline 8. & FK saat pemasangan PVD & - & - & Safety factor & \\
\hline 9. & FK timbunan awal tahap 1 & - & - & Safety factor & $\rightarrow$ \\
\hline 10. & FK timbunan awal tahap 2 & - & - & Saferty factor & \\
\hline 11. & FK saat konsolidasi $90 \%$ & - & - & Safety factor & \\
\hline 12. & FK konstruksi eksisting jalan & - & - & Safety factor & \\
\hline 13. & FK operasi eksisting jalan & - & - & Safery factor & 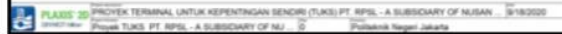 \\
\hline
\end{tabular}

Dari hasil analisis perhitungan Gambar 9, faktor keamanan (FK) untuk beban preloading tahap 1 dikombinasikan dengan PVD adalah sebesar 1,048 dan lereng mengalami deformasi maksimum sebesar 2,421 m. Angka keamanan yang diperoleh adalah lebih kecil daripada angka keamanan minimal untuk keruntuhan yaitu sebesar 1,50, sehingga lereng akan mengalami keruntuhan jika beban akibat berat sendiri bekerja secara maksimal. Namun, setelah beban preloading tahap 2 terjadi peningkatan angka keamanan sebesar 1,526 dan deformasi maksimum sebesar 0,6781 m. Pada kondisi konsolidasi 90\%, angka keamanan diperoleh 1,652 dengan maksimum deformasi sebesar 0,4221 m. Saat pelaksanaan konstruksi jalan akses dermaga / 
terminal TUKS diperoleh angka keamanan 1,819 dengan deformasi maksimum 0,3883 m (Gambar 10). Saat operasional dermaga dioperasikan dan masa layan jalan akses dicapai angka keamanan yang menurun sebesar 1,674 dengan deformasi sebesar 0,503 m sebagaimana ditunjukkan dalam Gambar 10. Nilai yang dicapai setelah 10 tahun masih dalam batas-batas toleransi angka keamanan yang disyaratkan, dengan demikian bisa diprediksi setelah tercapai keseimbangan deformasi maksimum angka terjadi lebih kecil setelah 10 tahun. Dari hasil - hasil angka keamanan yang diperoleh terlihat terjadi fluktuasi angka keamanan dan deformasi, dengan demikian bisa diketahui bahwa struktur dinding penahan tanah (revetment) efektif untuk menambah keamanan terhadap kelongsoran ke arah sungai dan sebagai beban imbang terhadap terjadinya pergerakan tanah.
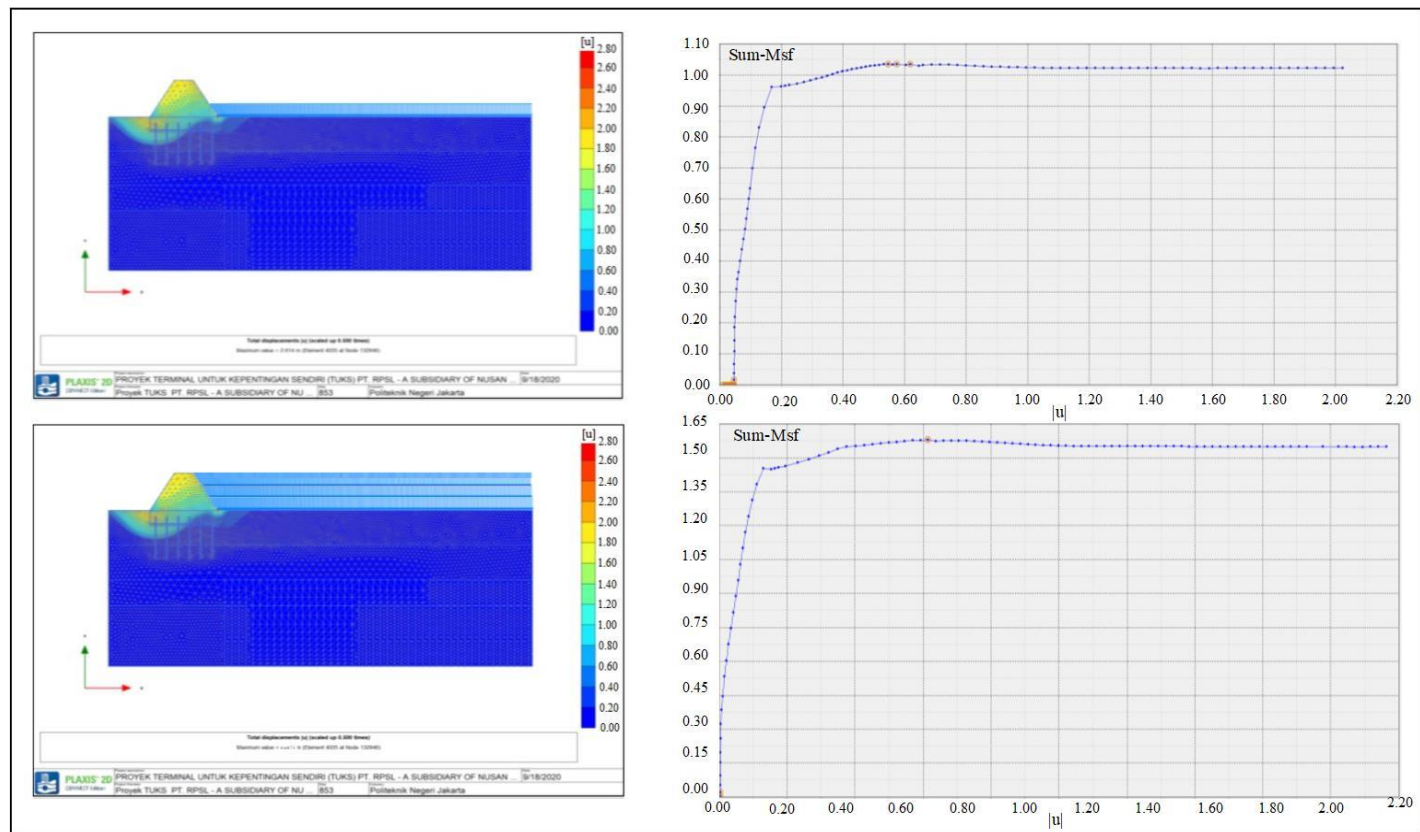

Gambar 9. Arah gerakan tanah dan penurunan tipikal akibat pre-loading tahap 1 dan 2 yang dikombinasikan dengan pemasangan PVD

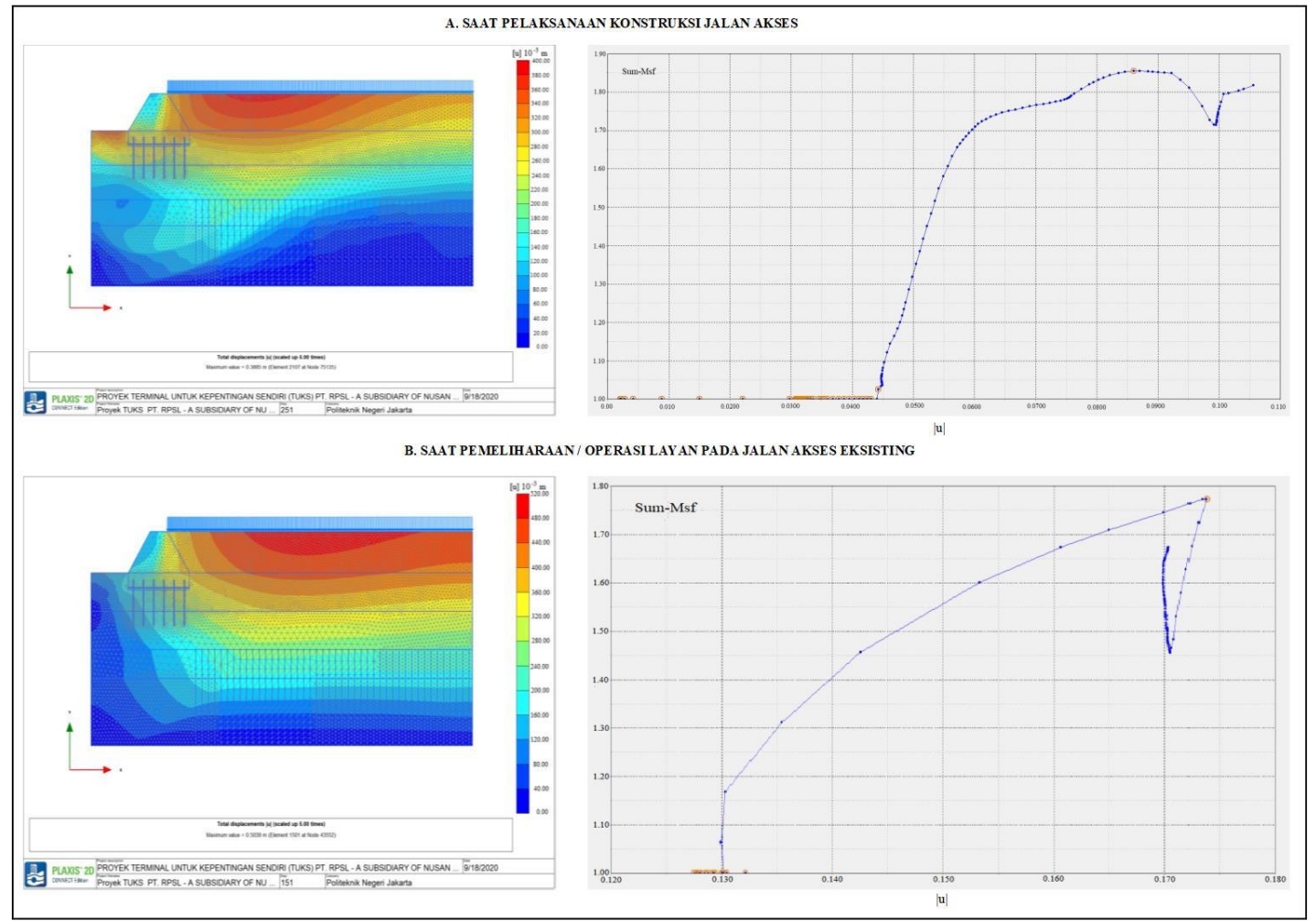

Gambar 10. Arah gerakan tanah dan penurunan tipikal saat pelaksanaan konstruksi jalan akses dermaga / terminal TUKS 


\section{RESUME DAN KESIMPULAN}

Dari uraian sebelumnya, maka desain dermaga memiliki fungsi ganda, yaitu sebagai bagian operasional pelabuhan dan sebagai penahan kelongsoran (sliding) dan atau pergerakan horizontal (horizontal displacement) lapisan atas lahan power plant. Oleh karena lahan power plant umumnya adalah lapisan lunak (soft soil), maka secara teoritis sistem pondasi dalam (deep foundation) harus diletakkan pada lapisan keras pada kedalaman $\geq 30 \mathrm{~m}$ sebagai kantilever untuk menahan pergerakan lateral di muka pelabuhan atau dermaga (jetty) TUKS. Hal ini menunjukkan bahwa sistem pondasi dalam umumnya tidak memerlukan proses konsolidasi (instant), dan tentunya relatif sangat mahal. Untuk menghindari biaya tinggi dalam pelaksanaan, maka dibutuhkan suatu alternatif-alternatif secara teknis. Salah satu metode yang digunakan dan relatif cocok dengan kondisi fisik tanah lunak di lokasi studi, maka digunakan sistem stabilisasi tanah lunak dengan menggunakan sistem PVD (prefabricated vertical drain).

Sehubungan dengan desain dermaga TUKS, maka digunakan sistem pemasangan tanggul pengikat (revetment) berupa tumpukan berbentuk trapesium dari bahan batu belah/kali/laterit, sehingga tidak terjadi longsoran saat pemberian prapembebanan atau preloading. Selain bisa digunakan sebagai areal atau lahan penumpukan material bio-massa, lahan juga mampu untuk menahan pergerakan lateral di atas lapisan tanah dan sekaligus menambah pra-pembebanan. Seiring dengan waktu, maka akan terjadi proses konsolidasi, dan lapisan tanah akan mengalami peningkatan parameter kekuatan geser (c' dan $\left.\phi^{\prime}\right)$ yang signifikan.

\section{DAFTAR PUSTAKA}

[1] A Verruijt. 2006. Soil Mechanic. Delft University of Technology Publisher.

[2] Barron, R. A. 1948. Consolidation of fine-grained soils by drains wells. Transportation Journal., ASCE, Vol. 113, Paper No. 2346. pp. $718-754$.

[3] Bolton, M.D. 1986. The strength and dilatancy of sands. Geotechnique 36, No. I. pp. 65-78.

[4] Bowles, J.E. 1997. Foundation Analysis and Design. The McGraw-Hill Companies, Inc. International Edition.

[5] Carter, M., and Bentley, S. P. 1991. Correlations of Soil Properties. Pentech, London

[6] Das, B.M. 2011. Principles of Foundation Engineering. Publisher, Global Engineering: Christopher M. Shortt $7^{\text {th }}$ Edition.

[7] Di Matteo, L, Valigi D, Ricco, R. 2013. Laboratory shear strength parameters of cohesive soils: variability and potential effects on slope stability. Bull Eng Geol Environ 72(1), pp. 101-106.

[8] El-Ramly, H., Morgenstern N,R, Cruden, D.M., 2003. Probabilistic stability analysis of a tailings dyke on presheared clay- shale. Can Geotech J 40(1), pp.192-208.

[9] Griffiths, D.V, Huang, J., Fenton. G.A. 2009. Influence of spatial variability on slope reliability using 2-D random fields. J Geotech Geoenviron Eng ASCE 135(10), pp.1367-1378.

[10] Holtz, R.D., and Kovacs, W.D. 1981. An Introduction to Geotechnical Engineering, Prentice Hall Inc., New Jersey.

[11] Hansbo, S. 1997. Practical aspects of vertical drain design. Proceedings of the 14th International Conference on Soil Mechanics and Foundation Engineering, Hamburg, Vol. 3, pp. 1749-1752.

[12] Jamiolkowski M., Lancellotta R., Pasqualini E., Marchetti S. and Nova R. 1979. Design Parameters for soft clays. General Report, Proceedings $7^{\text {th }}$ European Conference on Soil Mechanics and Foundation Engineering, No. 5, pp $27-57$.

[13] Jiang S,H., Li D.Q., Zhang, L.M, Zhou, C.B. 2014. Slope reliability analysis considering spatially variable shear strength parameters using a non-intrusive stochastic finite element method. Eng Geol 168(January), pp. 120-128.

[14] Kulhawy, F.H., and Mayne, P.H. 1990. Manual on estimating soil properties for foundation design, Report EL-6800 Electric Power Research Institute, EPRI, August.

[15] Lambe, T., and Whitman, R. 1969. Soil mechanics, John Wiley \& Sons Inc., New York.

[16] Look, K. 2007. Handbook of Geotechnical Investigation and Design Tables. Published by: Taylor \& Francis/Balkema.

[17] NAVFAC. 1986. Soil Mechanics. Design Manual 7.01, Naval Facilities Engineering Command, Virginia.

[18] Robertson, P.K., and Campanella, R.G., 1983a. Interpretation of cone penetration tests - Part I (sand). Canadian Geotechnical Journal, 20(4), pp. 718-733.

[19] Robertson, P.K., and Campanella, R.G. 1983b. Interpretation of cone penetration tests - Part II (clay). Canadian Geotechnical Journal, 20(4), pp. 734-745.

[20] Robertson, P.K. 2009. Interpretation of cone penetration tests - a unified approach, Canadian Geotech. J., 46(11). Pp.1337-1355.

[21] Schmertmann, J.H. 1978. Guidelines for cone penetration test, performance and design, US Federal Highway Administration, Washington, DC, Report FHWA TS-78-209.

[22] Suchomel R., and Masŝin, D. 2010. Comparison of different probabilistic methods for predicting stability of a slope in spatially variable c-/ soil. Comp Geotech 37(1-2), pp. 132-140.

[23] SNI 8460 - 2017, Persyaratan Perancangan Geoteknik. Badan Standardisasi Nasional, Jakarta.

[24] Taylor, D. W. 1948. Fundamentals of Soil Mechanics. Wiley, New York.

[25] Zhang J, Tang WH, Hon M, Zhang LM (2010) Efficient probabilistic back-analysis of slope stability model parameters. $J$ Geotech Geoenviron Eng ASCE 136(1), pp: 99-109.

[26] Zhou G, Esaki T, Mitani Y, Xie M, Mori J (2003) Spatial probabilistic modeling of slope failure using an integrated GIS Monte Carlo simulation approach. Eng Geol 68(3-4), pp. 373-386. 